\title{
Um movimento contra a violação de direitos: a Estrada do Engenho resiste
}

\author{
A movement against the violation of rights: \\ Estrada do Engenho resists
}

\author{
Nino Rafael Medeiros Kruger [I] \\ Caroline Krüger [II] \\ Cristine Jaques Ribeiro [III]
}

\section{Resumo}

Este artigo discute a garantia do direito à moradia a partir de uma reflexão sobre uma Ação Civil Pública (ACP) voltada à remoção da comunidade da Estrada do Engenho, no município de Pelotas. Com base em um movimento enraizado no método crítico dialético, tendo como esteira a pesquisa militante, a ação do Estado é problematizada, e rememoram-se a história da comunidade, as transformações ocorridas e as táticas desenvolvidas pelo mercado imobiliário e pelo poder público. Questionam-se, ainda, a produção histórica de racionalidades excludentes e os problemas oriundos da má gestão das políticas públicas. Como resultado, um trabalho coletivo é desenvolvido e são construídas linhas de ação, possibilitando a desestabilização do processo, protegendo e preservando modos de habitar da comunidade local.

Palavras-chave: direito à moradia; política pública de habitação; resistência; Pelotas; Estrada do Engenho.

\begin{abstract}
The article discusses the guarantee of the right to housing starting from a reflection on a Public-Interest Civil Action aimed at the removal of the Estrada do Engenho community, in the municipality of Pelotas (Southern Brazil). Based on a movement rooted in the critical dialectical method and on militant research, the State's action is problematized, and the history of the community, the transformations that have taken place, and the tactics developed by the real estate market and the government are recalled. The article also questions the historical production of excluding rationalities and the problems arising from the poor management of public policies. As a result, collective work is developed and lines of action are built, enabling the destabilization of the process, protecting and preserving the ways of living of the local community.
\end{abstract}

Keywords: right to housing; housing public policy; resistance; Pelotas; Estrada do Engenho. 


\section{Introdução}

A presente escrita é fruto de um trabalho que vem sendo desenvolvido desde o ano de 2016 no município de Pelotas, estado do Rio Grande do Sul (RS). No qual, originalmente um grupo de estudantes de Arquitetura e Urbanismo e pesquisadores do campo do Serviço Social, vinculados a um programa de Política Social e Direitos Humanos, trabalhavam no mapeamento das áreas de ocupação reconhecidas pela municipalidade como irregulares. Estes passaram a fazer o acompanhamento e a assessoria técnica a uma comunidade que vinha sendo ameaçada por um processo de remoção movido pelo Ministério Público Estadual (MP), que teve início em 2008.

Nesse contexto, a Ação Civil Pública (ACP) n. 022/1.14.0007280-6 (Rio Grande do Sul, 2016) voltava-se para a remoção da comunidade residente no corredor da Estrada do Engenho. 0 processo tramitava há oito anos em juízo, tendo um Termo de Ajustamento de Conduta (TAC) lavrado e assinado pelo então prefeito e pelo promotor do MP, no qual assumiam compromisso e datavam a remoção, sem que nunca tivessem ouvido a comunidade residente no local que se tornava em alvo de uma ação de violação de direitos.

A aproximação desses pesquisadores a tal contexto se deu, em princípio, no intuito de entender o processo que se desdobrava sobre o território habitado pela comunidade. Entretanto, eles se deparam com um quadro de total falta de informações quanto à ação jurídica por parte do grupo ameaçado, cujas famílias sabiam somente a data posta como limite para sua permanência no local, dia 15 de novembro de 2017.
Tal situação levou os pesquisadores a organizarem uma equipe de apoio técnico-social e jurídica para melhor compreensão da questão colocada, de modo a avançarem munindo a comunidade de informações, visando à busca da garantia dos direitos constitucionais do grupo ameaçado. ${ }^{1}$ Esse processo se deu através do acompanhamento semanal da comunidade, visitas nas quais foram trabalhadas, a partir da escuta e da rememoração dos fatos que levaram a comunidade a ocupar o território, suas memórias, a relação com a cidade, os vínculos estabelecidos com/no território e os processos de significação produzidos. De modo que foram sendo percebidos modos de habitar $^{2}$ de pertencimento, situação esta que impulsionou a reflexão quanto ao desenvolvimento de estratégias voltadas para garantia dos direitos da comunidade.

A partir dessas estratégias, primeiramente se construiu um questionário semiestruturado que foi aplicado para as 56 famílias residentes no local, com o objetivo de reconhecer as condições socioeconômicas da comunidade e a infraestrutura de cada família, além de confirmar as informações que vinham sendo coletadas a partir das trocas e escuta.

Com as informações acessadas pelo questionário, passou-se a realizar reuniões nas quais se trabalhou a técnica de grupo focal (Imagem 1). De acordo com essa técnica, reuniam-se, no mesmo ambiente, durante um período previamente acordado, um pesquisador, acompanhado por seu grupo de trabalho (nesse caso, uma equipe interdisciplinar composta por quatro integrantes), e grupos de dez moradores que representavam suas famílias, público-alvo da primeira etapa da pesquisa. 
Imagem 1 - Trabalho em Grupo Focal com a comunidade

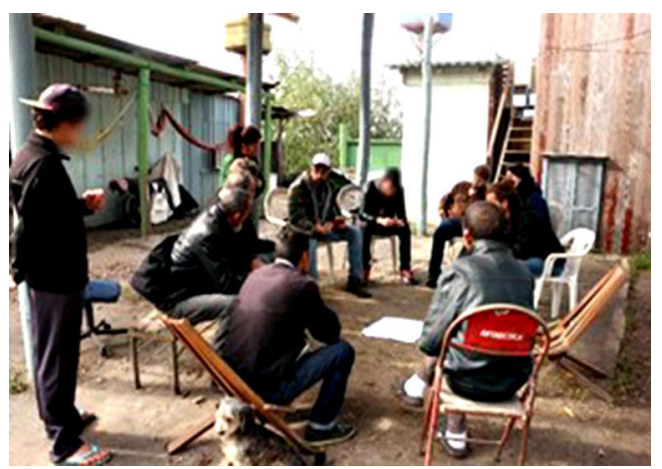

Fonte: Estrada do Engenho (2017).
Imagem 2 - Audiência pública sobre a remoção dos moradores

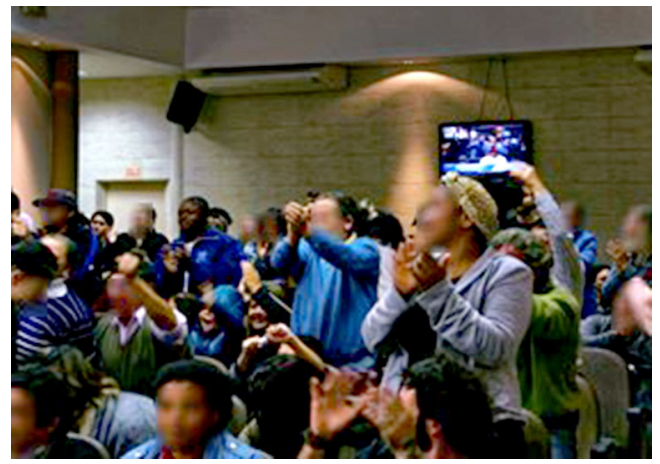

Fonte: Estrada do Engenho (2017).

Com o diálogo e a discussão produzidos, foram coletados dados acerca da investigação. De modo que, por meio dos saberes locais e conhecimento das demandas coletivas, foram construídas linhas de ação. Vale destacar que a técnica de grupo focal foi preconizada para que os temas propostos fossem discutidos, e não apenas respondidos de forma direta; resultando em uma construção coletiva, que possibilitou um espaço de reflexão e análises para/pelo próprio grupo (Morgan, 1997).

A partir dessa construção, foram organizadas linhas de ação, visando a ampliar o debate e a problematizar questões relativas ao processo, buscando obter respostas dos entes quanto à situação jurídica, uma vez que a comunidade não era parte na ACP. Assim, organizaram-se primeiramente audiências públicas (Imagem 2). No entanto nas quais a não participação de representantes do judiciário provocou o desenvolvimento de atividades de rua, como caminhadas e ocupação de áreas públicas voltadas à denúncia da situação. E, como parte destas ações, foi elaborado um projeto de pesquisa no campo do Serviço Social - construído e em parte aqui apresentado -, a partir de oficinas que foram feitas junto à comunidade.

A pesquisa tornou-se uma estratégia de aproximação aos promotores e um meio de acessar as informações sobre trâmites do processo jurídico. Sendo, ainda, um instrumento de mobilização e denúncia quanto aos direitos violados e uma ferramenta de ação dentro de um amplo espectro de reflexão crítica (Netto, 2011).

Desse modo, visando a compreender como têm se desenvolvido as relações de produção e apropriação do espaço urbano no sistema capitalista, foi desenvolvida uma pesquisa militante; perspectiva de investigação que possibilita, aos pesquisadores, partilhar e participar do projeto sociopolítico de seu campo. Abandonando a posição de observadores, 
eles podem se transformar em agentes promotores de transformação. Envolvimento de enriquecimento do processo de pesquisar, no qual se tem a possibilidade de reconhecimento e construção horizontal do conhecimento com os agentes envolvidos em cada etapa do processo (Cunha e Santos, 2010).

Assim, a partir de uma análise de conteúdo sobre a ACP, o processo jurídico serviu como lente para observação da complexa realidade posta. De modo que se recuperaram, na história da comunidade, as origens das disputas colocadas sobre o território, sem, contudo, pretender esgotar a reflexão ou o processo de discussão sobre a temática trabalhada, mas buscando a transformação da situação apresentada, na observação dos movimentos e conflitos estruturantes do processo dialético (Netto, 2011); na problematização quanto à possibilidade de instrumentalização da ACP em sua abordagem sobre uma realidade múltipla, com incidência histórica e documentada de atores e interesses diversos.

\section{Um debate necessário}

Promover essa discussão no campo acadêmico se dá a partir da compreensão de que a universidade, enquanto produtora de saber, é espaço político de conflito entre forças sociais (Papaléo, 1991); um universo produtor de conhecimento validado enquanto científico que "tem sido correntemente evocado pelos que pretendem reduzir as políticas [...] a meras soluções técnicas" (Acselrad; Mello e Bezerra, 2009, p. 31). Julga-se necessário enfrentá-las, através da produção de resistências que partam do reconhecimento e/ ou produção de novos conhecimentos capazes de banir a exclusão, em qualquer nível.
Por isso, as reflexões aqui expostas carregam a inquietação de um outro paradigma de produção do saber, calcado no movimento enquanto fundamento para o desenvolvimento de processos reflexivos, que esteiam a busca pela associação das experiências sociais à produção acadêmica. Em tensão, reconhecendo no conflito a possibilidade de maior abertura à classe trabalhadora e aos grupos historicamente marginalizados, na participação dos processos de transformação social, trazendo contribuição efetiva para a mudança da realidade exposta, marcadamente desigual (Bringel e Varela, 2016).

Esse conflito se apresenta como estratégia para o enfrentamento aos processos de apropriação do espaço urbano pelo poder privado, que visam à obtenção do máximo lucro por meio da expropriação e exploração dos homens e da natureza, produzindo um "modelo de injustiça social" que é aqui enfrentado por aqueles que fazem oposição à atual estrutura que beneficia pequenos grupos (Nigro, 2007, p. 17).

0 grande desafio do trabalho, nesse contexto, é encarar o entendimento da estrutura social transversal e atuar de forma a diagnosticar onde se estabelecem esses processos e se materializam práticas que com ele corroboram. Pois, compreendendo que a divisão socioespacial das cidades foi definida por racionalidades herdeiras do processo colonial - que negam a absorção da mentalidade excludente dos colocados em situação de vulnerabilidade pelas políticas urbanas e habitacionais -, os territórios diversos tornaram-se áreas de articulação da desumanização dos sujeitos, expostos a práticas de múltiplas exclusões, podendo ter, conforme "julgamento", alterados os rumos de suas vidas. Insurgentes, grupos que 
foram colocados diante de tal situação resistem e, dessa forma, a partir da experiência vivida, subvertem paradigmas, produzem outras epistemologias, novos conhecimentos.

A esse respeito, o debate teórico construído na relação entre os pesquisadores e a comunidade, alinhado a ações de mobilização prática, fez com que tal realidade se tornasse pública; tornando percebido que o território (Saquet e Silva, 2008) em estudo, localizado à margem do canal São Gonçalo, era objeto de disputa após ter despertado o interesse do mercado imobiliário, em ascensão no local (Idealiza, 2014).

Nesse contexto, o mercado imobiliário passou a impingir construções de grandes e variados empreendimentos que transformaram a região e a tornaram espaço de confluência de múltiplos interesses e conflitos (Filho, 2017), colocando em enfrentamento sobre a localidade modos de habitar distintos, caracterizados como projetos civilizacionais em oposição prática e teórica. Essa estratégia faz desaparecer a imagem e a ideia dos citadins - habitantes da cidade em sua totalidade, com direitos e deveres em relação a ela -, reduzindo a cidadania aos citoyens - aqueles aos quais o Estado reconhece o status de portadores de direitos (Lefebvre, 2001).

Neste ínterim, o primeiro modo de habitar é caracterizado com o conceito de polis, que se traduz como um lugar de encontros e confrontos que materializam a vida na cidade (Vainer, 2013). Tal conceito, posto em relação ao território em destaque, possibilita sua apreensão enquanto espaço no qual grupos distintos se encontram, constroem modos de existir, de trocas e de integração ao ambiente, recuperando a ideia de citadins. Já o segundo é reconhecido como city. Caracteriza-se como um projeto que materializa, nos espaços, a mercantilização, a objetificação e o sujeitamento aos interesses econômicos privados e do mercado, excluindo aqueles que foram anteriormente impossibilitados de concorrer no mercado das cidades (ibid.), e concretiza a ideia de proteção aos citoyens.

Os estudos, pesquisas e problematizações teóricas, alinhados à ação social dos agentes, oportunizaram que os múltiplos interesses em disputa fossem noticiados pela imprensa (Cogoy, 2017; Munaretto, 2017; Coll, 2017). Assim como fizeram, também, com que uma petição apresentada pelo grupo fosse aceita pelo responsável pelo julgamento do processo, tornando a comunidade parte dele e possibilitando que fosse feita, em juízo, a problematização dos temas relacionados ao território.

Assim, passou-se a refletir sobre as raízes da problemática e as ações do Estado ante a expansão do mercado imobiliário, situação que foi agravada pela ACP. A ação movida pelo MP contra Prefeitura Municipal (PM) a acusava de negligência na fiscalização das ocupações sobre as Áreas de Preservação Permanente (APP) e enquadrava o território a esses termos, imputando penalidade às famílias residentes, e não sobre a PM. Exigia-se a remoção da comunidade sob a alegação de que estaria em uma APP, causando danos ao meio ambiente e encontrando-se sob risco. Problema amplamente abordado na literatura sobre justiça ambiental, em que os causadores dos danos não são responsabilizados, recaindo o peso sobre os grupos colocados em situação de vulnerabilidade (Acselrad, 2010).

Sobre esse panorama, de maneira coletiva, foram realizados estudos e construídas problematizações, impulsionando a reflexão sobre tal realidade diante da ACP. Assim, 
o desenvolvimento da pesquisa se deu em aliança com a comunidade, assumindo compromisso com análises e reflexões voltadas a compreender e desvelar processos outros que poderiam se ocultar em práticas estatais e jurídicas. Processos estes históricos, que refletem o aprofundamento das desigualdades socioambientais e territoriais na localidade, quadro também agravado em nível nacional (Acselrad; Mello; Bezerra, 2009).

Portanto, procurou-se contribuir de forma teórica e prática para construção de estratégias capazes de transformar a realidade concreta, desenvolvendo-se a pesquisa a partir de um olhar socialmente comprometido, assentado sobre a produção e a reprodução das contradições sociais de forma politicamente posicionada (Bringel; Varella, 2016).

\section{$\mathrm{Na}$ origem da cidade as raízes da exclusão}

Para compreender como se chegou aos processos de disputas que se desdobram sobre o território em análise, é pertinente o desenvolvimento de uma breve rememoração da origem da cidade de Pelotas e da gênese da comunidade da Estrada do Engenho. Cabe destacar que essa rememoração construída com a comunidade busca situar o papel histórico do território ante o processo de urbanização local. Perspectiva que torna possível a observação da cidade enquanto obra, que se constrói e se consome, e da qual se apropriam seus habitantes, objetiva e subjetivamente - um constructo social, fruto de inter-relações socioespaciais, e uma mercadoria para o capitalismo (Kowarick, 1993).
Parte-se, notadamente, da ideia de que o local do qual se pretendia remover as famílias, desde sua origem, apresenta-se como espaço em que grupos excluídos da proteção estatal em princípio negros escravizados e, posteriormente, grupos de trabalhadores em situação de extrema vulnerabilidade - reuniram-se para habitar e desenvolver suas atividades laborais, mesmo anteriormente à constituição da cidade. Assim, antes de ser elevada a freguesia em 1812, na então sesmaria de Pelotas, formou-se o primeiro arraial do distrito - o Passo dos Negros. Espaço a ser rebatizado, um século depois, de Estrada do Engenho (Gutierrez, 2001).

As primeiras referências que se têm sobre o município, datadas de 1758, relacionam sua origem à da Estrada do Engenho. No ano citado, o então governador do Rio de Janeiro, Conde de Bobadela, fez a doação, a Tomás Luís Osório, da sesmaria, que foi dividida e originou as primeiras estâncias que sediaram as charqueadas que dão início a cidade. Esse movimento de divisão territorial foi impulsionado pelo desenvolvimento econômico oriundo do fornecimento de alimentos, especialmente o charque - atividade intrinsecamente dependente do labor negro e que fez surgir o Passo dos Negros e, dele, o município (Mapa 1).

Nessa localidade, ainda no final do século XVIII, construiu-se o primeiro atracadouro de navios, no qual se recebiam os escravizados e as mercadorias advindas, sobretudo, da Europa. Cenário que fazia do território em análise a principal porta de acesso à sesmaria, onde se estabeleceu o posto de cobrança de impostos para a coroa portuguesa e de onde se escoava a produção saladeril - processo desenvolvido, segundo Gutierrez(ibid.), por quase um século. 
O historiador Al-Alam (2017), escrevendo sobre a origem e o desenvolvimento do município, aponta que houve, nesse território, a tentativa de fundação da cidade, por meio de projetos desenvolvidos para maior concentração populacional. 0 que não se efetivou, devido a interesses dos loteadores padre Felício e Antônio dos Anjos, que intentavam vender terrenos de suas propriedades ao norte do local. Sobre esse fato, Gutierrez (ibid.) destaca, ain$\mathrm{da}$, que os problemas gerados pelos dejetos da produção do charque lançados no canal que margeia o território e a intensa concentração de escravizados que circulava pela localidade foram utilizados como subterfúgios para a efetivação dos interesses dos loteadores. Situação que impediu o avanço do primeiro projeto de urbanização desenvolvido para a cidade.

Desses apontamentos iniciais, observa-se que, em sua origem, a cidade relaciona-se a uma doação envolvendo atores de grande poder e influência, possuindo, em sua gênese, interesses privados sobrepostos ao bem coletivo. Pois, historicamente, o canal que permeia a cidade - onde se localiza atualmente a Estrada do Engenho - foi alvo da descarga de dejetos. Isto se deu, inicialmente, como consequência da primeira etapa de desenvolvimento do

Mapa 1 - Passo dos Negros (século XIX)

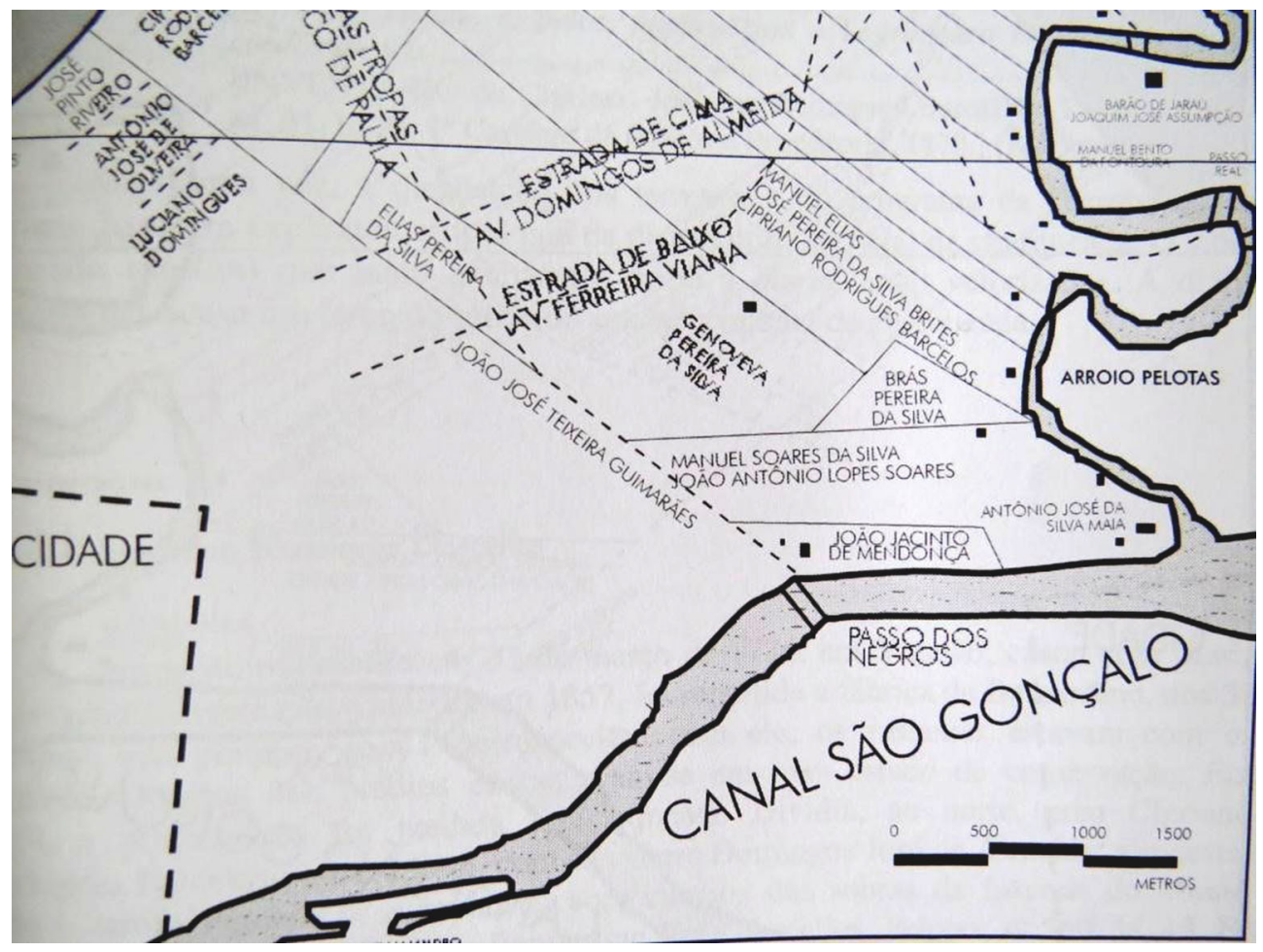

Fonte: Gutierrez (2001, p. 143). 
município, impulsionada pela intensa atividade comercial sediada nessa região, onde foram controladas mercadorias produzidas com trabalho de escravizados (Al-Alam, 2017),

Posteriormente a essa fase, já com a cidade consolidada segundo o ordenamento dos loteadores, no segundo período de desenvolvimento econômico local, as atividades são marcadas pelo beneficiamento de arroz. Essa atividade marcou o período de transição entre os séculos XIX e XX, e novamente o espaço marginal do canal São Gonçalo se tornou central aos interesses econômicos. Na margem do canal, foi construído o primeiro engenho de beneficiamento de arroz da região (Rheingantz, 2004) - o Engenho São Gonçalo, também chamado de Engenho Pedro
Osório. Altera-se, então, a morfologia local, e o território é rebatizado: o Passo dos Negros torna-se Corredor da Estrada do Engenho (Defender, 2010).

A partir da instalação do Engenho, o território que já era marcado pela presença da população negra, recebe o acréscimo de uma vila de trabalhadores que sustentam o funcionamento do Engenho (Rosenthal e Gonçalves, 2014). Algumas décadas depois, institui-se, no local, uma vila de pescadores, que acabam não sendo beneficiados pelos movimentos de desenvolvimento de infraestrutura urbana que ocorrem em expansão ao norte da cidade. Isto porque o território à margem do canal era considerado, no início do século XX, uma região não propícia à construção de moradias.

Mapa 2 - Localização da Estrada do Engenho no mapa de sistema viário (2008)

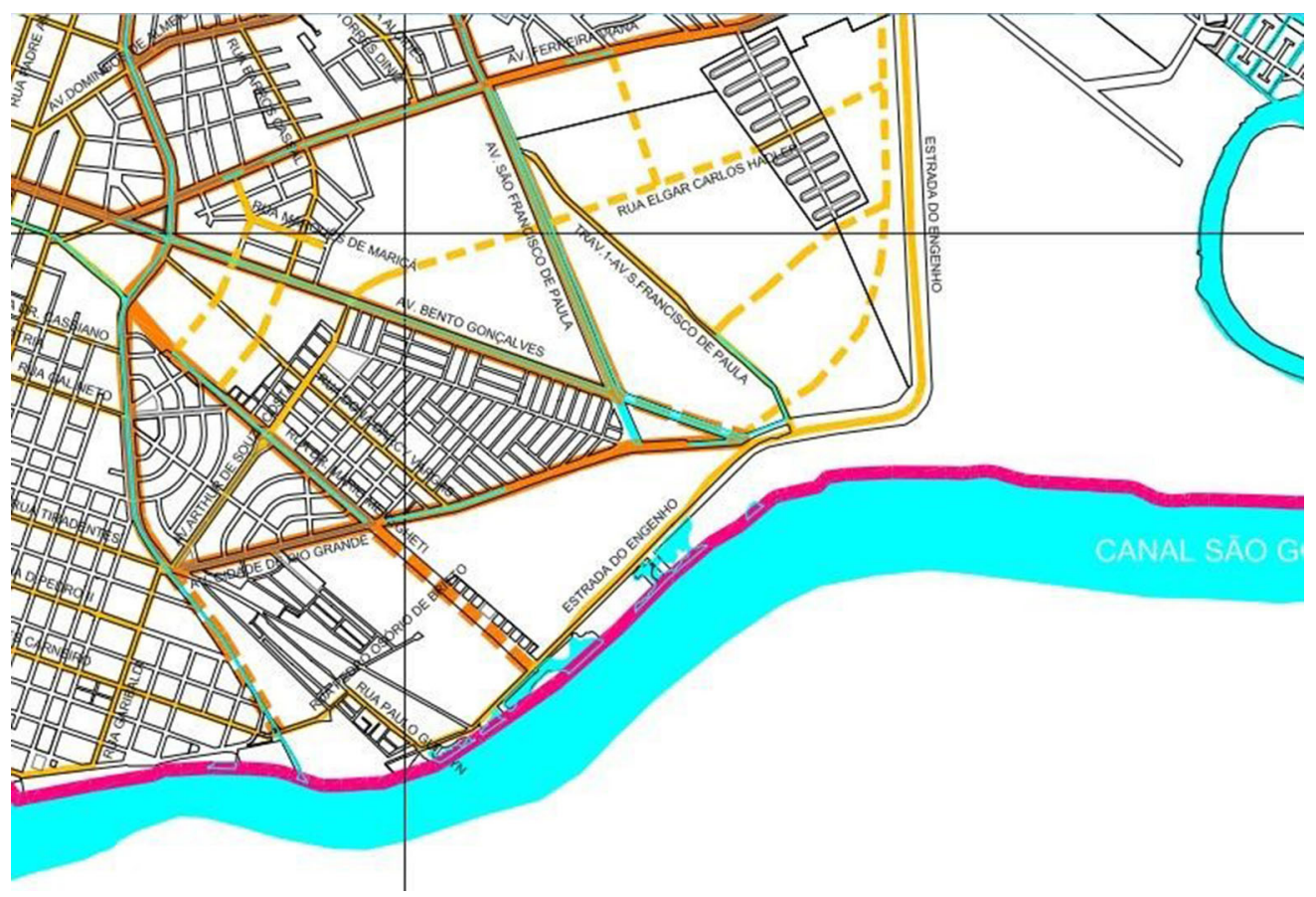

Fonte: Pelotas (2008). 
Sem valor para o mercado, torna-se, nos termos de Martins (1997), um espaço de inclusão marginal, instável e precário.

Assim, o território foi habitat de comunidades originárias, grupos tradicionais e daqueles impossibilitados de acessar o mercado formal de terras por dois séculos (Gutierrez, 2001). E, diferentemente das áreas valorizadas na cidade, nas quais se desenvolveram investimentos em obras de infraestrutura, a Estrada do Engenho ficou "esquecida", e se constituíram os espaços que consubstanciam a hierarquização social, abrigos para os herdeiros da alienação (Maricato, 2015), espaços de operação da acumulação por despossessão urbana (Harvey, 2005).

Para permanência às margens do canal, nesse território desprovido de investimentos públicos, os diferentes grupos que o ocupavam acabaram desenvolvendo formas particulares de se relacionar com o ambiente, construindo moradias com tecnologias próprias, condizentes com sua relação com a natureza e recursos financeiros, relacionadas com suas atividades laborais, incidindo sobre seu modo de habitar. Desse modo, escravizados, outrora trancafiados em senzalas, tornaram-se operários lançados em cortiços, catadores de resíduos sólidos e prestadores de serviço de toda a ordem, aos quais se somaram pescadores dependentes de palafitas - periféricos, excluídos da cidade e do mercado formal de trabalho.

Formando uma área de potencialização dos processos de exclusão (Martins, 1997), o território consolidou-se enquanto região para moradia daqueles colocados em situação de extrema vulnerabilidade, pelos quais o mercado imobiliário e construtor não tem interesse. No território, passa a operar o passivo da economia urbana desigual e combinada (Oliveira, 2013). Enquanto as áreas nobres ficam com o bônus do processo de urbanização, na Estrada do Engenho opera o ônus, de uma dinâmica na qual os aspectos avançados do modo de produção capitalista se nutrem da produção de formas de atraso, que se desdobram e retroalimentam de forma simultânea.

A negação aos benefícios da urbanidade e do acesso à cidade cria o negativo - a não cidade -, na qual faltam infraestrutura, equipamentos e serviços, sustentando uma das contradições intrínsecas da modernização capitalista: o negativo do desenvolvimento que retroalimenta e impulsiona seu último. A (im)produção fortalece-se na falta de infraestrutura para potencializar a exclusão (Martins, 1997), aprofundando desigualdades (Oliveira, 2013).

Até a década de 1970, nenhuma ação urbanística para a melhoria das condições de existência da população da Estrada do Engenho é desenvolvida, apenas obras esparsas de baixa ou nenhuma qualidade. 0 primeiro projeto planejado para a qualificação do território surge somente no ano de 2001 (Ribeiro, 2017). Vale destacar que este não conta com a presença da população historicamente nele residente, como pode ser observado na Imagem 3.

No entanto, esse projeto não foi concretizado (Imagem 3). A racionalidade excludente que ele expressa e suas influências serão notórias na implementação do III Plano Diretor Municipal (PDM), que ocorreu sete anos mais tarde. Neste, será possível observar questões que relacionam os interesses do mercado aos da PM e da ACP. Sendo estes responsáveis pelo desencadear dos conflitos sobre o território, como se discutirá especificamente adiante. 
Imagem 3 - Projeto de requalificação da orla do canal São Gonçalo

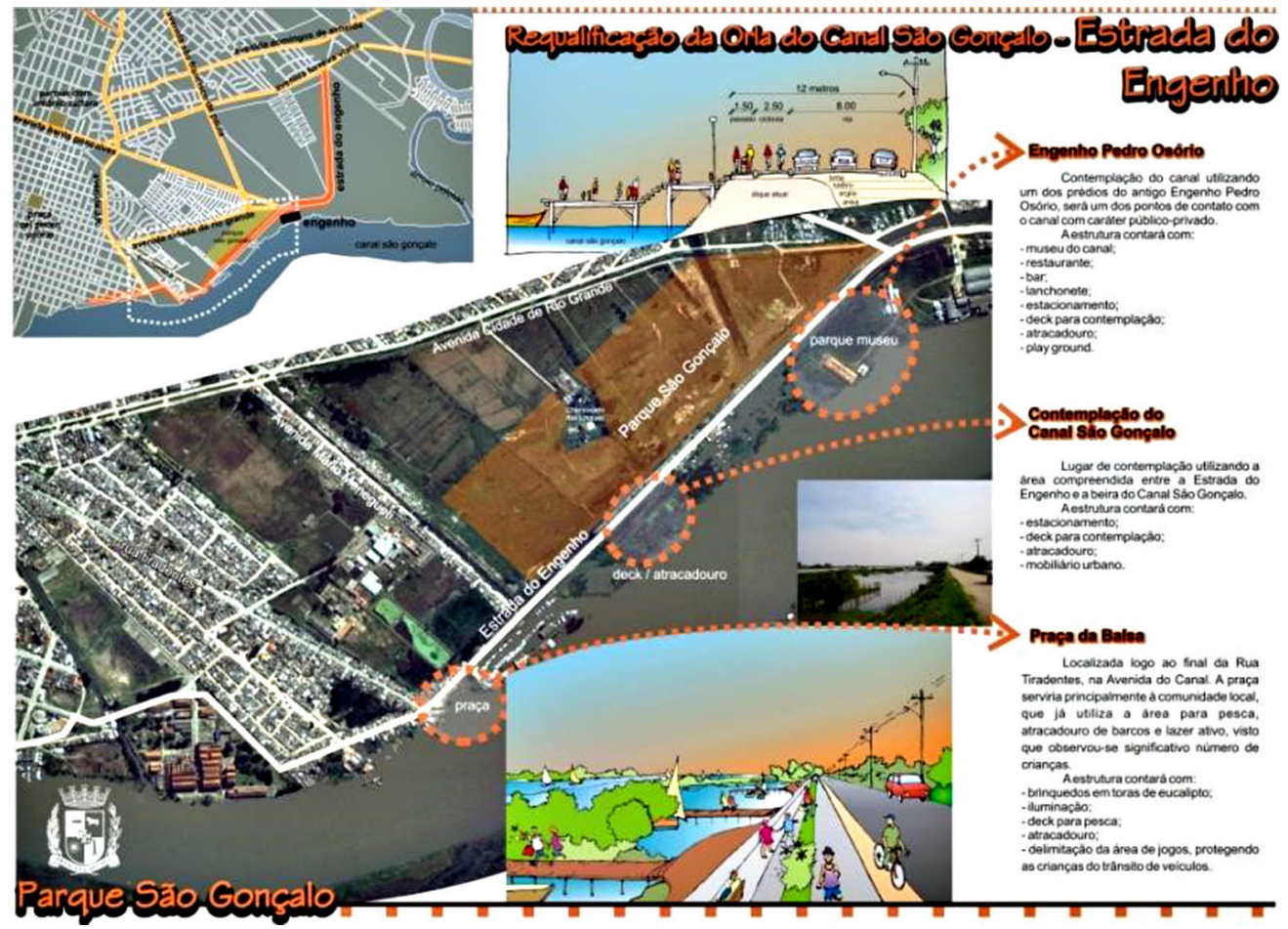

Fonte: Ribeiro (2017).

\section{Quando mudam os ares: o III Plano Diretor e o interesse do mercado}

Uma das marcas históricas de gestão no município de Pelotas é o desenvolvimento de ações para consubstanciar interesses de mercado. Em legislação do ano de 1881, que trata da demarcação do perímetro urbano, é possível vislumbrar tais estratégias. Para atender aos interesses dos industriais que desejavam colocar trabalhadores em vilas operárias, a construção de cortiços nos arredores do centro da cidade foi proibida. Consequentemente, issos fez com que o principal modelo de moradia dos trabalhadores acabasse, sendo imposta a sujeição ao modelo de moradia que rebaixava os salários ou a expulsão para áreas sem infraestrutura (Moura, 2006).

Dos anos finais do século XIX até as primeiras décadas do século $X X$, jornais locais apresentam relatos que expunham o tensionamento dos construtores para que a municipalidade beneficiasse o desenvolvimento de seus projetos. As reivindicações do mercado que surgia iam do fornecimento de terras e desenvolvimento de legislações, até a execução de 
obras públicas voltadas à facilitação dos processos e atendimento aos interesses das elites (ibid.). Assim, o Estado passa a executar medidas voltadas para maior sujeição dos trabalhadores aos empresários, através de estratégias que possibilitam o aumento da acumulação. Um processo de "industrialização a baixos salários" com equivalente em uma urbanização a baixos salários (Maricato, 2015, p. 27).

Tal situação, ainda que variando de acordo com questões econômicas macroestruturais, não se alterou no decorrer dos anos. A partir de 1968, com a promulgação do I PDM (Pelotas, 1968), que foi substituído, em 1980, pelo II PDM (Pelotas, 1980), a questão agravou-se. Isto porque o planejamento de ações voltadas à materialização de processos ainda maiores de exclusão social é despendido. Desenvolvem-se territórios precários, concretizando-se a máxima do atrelamento da pobreza, a privação de infraestrutura urbana básica, criando territórios nos quais se fortaleceram os estigmas produzidos no século XIX (Kruger, 2018).

Pautado pelo Estatuto das Cidades (Brasil, 2001), o III PDM (Pelotas, 2008) registrou importantes avanços na direção da garantia de direitos para os habitantes do município. 0 documento reforçou a necessidade de adoção de medidas voltadas ao cumprimento da função social da cidade e da propriedade. Reconheceu a multidimensionalidade das potencialidades do município, reiterou a garantia do direito à cidade como "direito à terra urbanizada, à moradia, ao saneamento ambiental, à infraestrutura, ao transporte e aos serviços públicos, ao trabalho e ao lazer" (ibid., p 2). Reforçou, ainda, a importância da gestão democrática e participativa na execução das políticas territoriais e, em seis artigos distintos, abordou especificamente o território da Estrada do
Engenho, explicitando os procedimentos que deveriam ser desenvolvidos para a integração deste à cidade.

No artigo 88, parágrafo 2, o III PDM destacou que se deve "evitar a expulsão de seus moradores, mediante a utilização de instrumentos jurídicos" (ibid., p. 36). Em seguida, reconheceu o território como uma Área Especial de Interesse Social (Aeis) de tipo 1, que se localiza em "área de preservação ambiental, ocupada por população de baixa renda" (ibid., p. 38), classificando-a como uma Área de Preservação Permanente Ocupada (Appo), na qual se deve adequar a propriedade de uso do solo a sua função social.

Nos artigos 60, 87, 88 e de 90 a 93, a legislação apresenta uma série de ações que deveriam ser executadas no território, apontando para estratégias de geração de trabalho e renda; regularização fundiária; desenvolvimento de infraestrutura urbana; disponibilização de recursos para recuperação de moradias; recuperação ambiental das áreas degradadas, etc. (ibid.). Contudo, a não execução dessas ações abriu a possibilidade para o mercado projetar empreendimentos para o local, contando com as facilidades estabelecidas em lei.

Nesse sentido, o III PDM discorreu sobre a necessidade de transferência da centralidade do município para a região da Estrada do Engenho, tratada como a região do São Gonçalo. Alegou que o centro urbano de Pelotas (próximo à região) deveria ser preservado (ibid.). Essas questões somadas incidem sobre um processo de valorização do território por parte do mercado, de modo a desenvolver um conjunto de empreendimentos imobiliários e comerciais na região. Obras materializadas sem respeito à legislação ambiental vigente, como se pode observar nas Imagens 4 e 5. 
Imagem 4 - Território antes do aterramento das áreas de banhado, junho de 2010

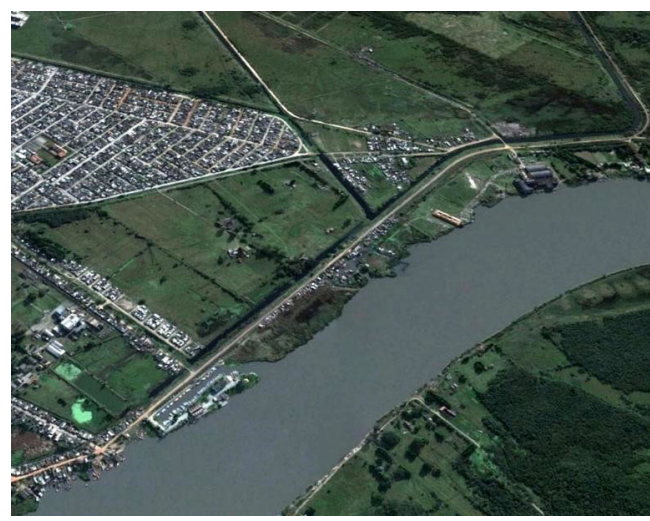

Fonte: Google (2017a).
Imagem 5-Território após aterramento das áreas de banhado, outubro de 2016

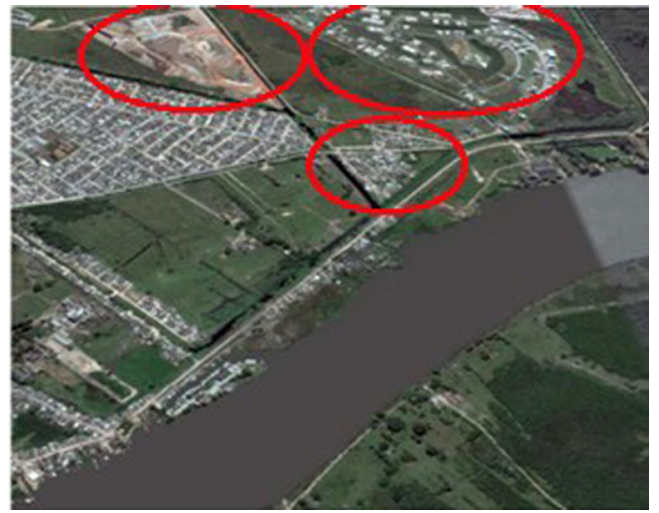

Fonte: Google (2017b).
Segundo a legislação ambiental estadual, no artigo 155, parágrafo 1 , áreas ao longo de rios ou cursos d'água, manguezais, marismas, nascentes e banhados são consideradas APP (Rio Grande do Sul, 2012) e não poderiam ser aterradas. Porém, para a construção dos empreendimentos, foram obtidas autorizações.

Paralelamente a esses processos, que passaram a ocorrer após 2008, foi que surgiu a denúncia, ao MP, quanto à ocupação da área de APP no território, por "grupos que estariam causando danos ambientais". De modo que os primeiros fatores apontados na ACP não relacionavam o ocorrido à construção dos grandes empreendimentos no contexto dos interesses que se colocavam em conflito. Pesavam, antes, sobre a comunidade - famílias que habitavam historicamente o território

Observou-se, então, que a legislação utilizada para criminalizar a ocupação histórica era a mesma negligenciada, quanto ao aterramento dos banhados para as novas construções. Passou-se, assim, a problematizar o fato de a legislação que embasa a ACP estar sendo utilizada para facilitar a materialização de ações de exclusão sobre os grupos que habitam o local, possibilitando ou operando, desse modo, uma cirurgia urbanística, ou seja, a remoção daqueles que foram historicamente excluídos nos processos urbanísticos anteriores.

Importante retomar que tal situação demonstra a realidade de muitas outras comunidades espalhadas pelo País, que têm negadas as condições de acesso a moradia e trabalho, sob as exigências de um mercado movido por estruturantes históricos, que reforçam as condicionalidades impostas pelas políticas públicas para o acesso a direitos. Realidade que pauta o contexto brasileiro, fazendo-se regra, pois diz respeito à maior parcela da população do País (Maricato, 2015). 
Nesse escopo, ao aprofundar as análises da ACP, a partir do conteúdo (Bauer e Gaskell 2012) - metodologia que possibilita a construção de conexões com o objetivo proposto -, buscou-se trazer resposta à questão de investigação, que foi relacionada aos documentos e legislações que abordavam a história do território e de seus habitantes. Desse modo, os pesquisadores foram levados a uma imersão na problemática vivida pela comunidade.

Sendo assim, o caminho percorrido foi de aprofundamento nas reflexões sobre a complexidade das questões que envolvem a trama das relações urbanas no território, construindo possibilidades de superação do problema colocado. Sendo repensadas constantemente as disputas expressas, para assim compreender as estratégias de apropriação e os impactos delas sobre o território e a população que nele habita. Apreendendo a dinâmica como manifestações da questão social ${ }^{3}$ - argumento de reivindicação de equidade na aplicação da lei -, buscou-se legitimidade social às lutas (Acselrad; Mello e Bezerra, 2009).

\section{Estrada do Engenho Resiste: um movimento}

Da não implementação dos estatutos apresentados pelo III PDM sobre a Estrada do Engenho ao não reconhecimento por parte da ACP das condicionantes históricas impostas sobre a comunidade, os interesses em conflito criaram um catalisador que impulsionava o processo de expulsão. Situações sobrepostas à justificativa retórica do processo jurídico de que o território é uma APP, na qual as famílias que nele habitam estariam causando danos ao meio ambiente e encontrando-se sob risco - estrutura e fundamento da ACP que justificava a remoção de um espaço alvo de mercantilização.

Desse modo, atribuía-se crime ao poder público municipal, acusado de não fiscalização sobre a ocupação de APP; e imputava-se pena sobre a comunidade. Não reconhecendo o acelerado aumento da ocupação sobre ele por parte dos grandes empreendimentos imobiliários, que não dialogavam com as formas históricas de ocupação. Encobriam-se, assim, as ações do mercado que produziam marinas, condomínios de alta renda e empreendimentos comerciais, ao mesmo tempo que aceleravam a vulnerabilização da comunidade, tornando os habitantes um reflexo da profunda desigualdade social concretizada na negação do direito fundamental à moradia (Pereira, 2013), uma série de movimentos aparentemente distintos que confluíam e conflitavam no local.

Um outro movimento é ainda destacado pela $A C P$, que apontou o aumento no número de famílias que se voltaram à ocupação da localidade na última década. Isto porque a ação jurídica não reconhecia ser este um grupo desprovido de condições de se inserir no mercado formal da moradia, vitimado pelo desemprego e pelo aumento nos valores de aluguéis, não alcançado pelas políticas de moradia do período - que deveriam ter o propósito de Ihes servir -, caso do Programa Minha Casa Minha Vida (PMCMV), que se voltava às faixas de maior lucratividade para o mercado (Pinto, 2016; Kruger, 2018).

Como consequência, famílias não atendidas pelo programa procuravam a área para fixar moradia e garantir minimamente sua subsistência. Movimento este denunciado na $A C P$, que não faz separação entre as famílias 
históricas residentes e o grupo afligido pelas variações econômicas e pela a crise, que buscou moradia no local. De modo que a população encontrada em área de risco, ou seja, a de menor renda, é responsabilizada pela ocupação e pelos danos. Assim, protege-se aqueles levados pela valorização financeira a esses espaços, grupo e projetos que não dialogam com as formas de vida preexistentes, que se impõem e causam tantos danos quanto os demais. Protege-se, também, a PM, acusada de negligência no trato com a fiscalização de APP e responsável pela planificação do PMCMV, que não alcançava as populações prioritárias, lançando-as em um processo de vulnerabilidade agravada. Esses grupos não eram alvo de nenhuma responsabilização.

Nesses termos, muitas são as ocultações, como o perfil socioeconômico e a historicidade dos grupos distintos que ocupam o território, uma estrutura fundada em relações estratificadas de classe e raça. Obscurecendo que, entre os prejudicados pela ACP, existem grupos originários, como: famílias de descendência de escravizados; trabalhadores que ergueram a cidade por meio do seu labor no charque e no engenho. Populações estas responsáveis pelo desenvolvimento econômico do município até a metade do século XX. Além destes, há pescadores artesanais que necessitam do canal para desenvolver sua atividade laboral. E, por fim, os excluídos do mercado formal de trabalho, impossibilitados de concorrer no mercado de aluguéis, grupo marcado pelo movimento da financeirização e elitização do mercado da habitação - uma das principais marcas desse setor no País (Boulos, 2015). Faz-se necessárias, aqui, uma abertura para aprofundamento desse debate no caso de Pelotas e a introdução nessa discussão da amplitude do problema habitacional local.

\section{Ocupação e resistência}

Neste item, serão trazidos alguns apontamentos sobre as áreas de ocupação irregular e a produção habitacional a partir do ano de 2008 em Pelotas. Ano de promulgação do III PDM, da disponibilização de recursos para o PMCMV (Galhardo, 2008) e do início da ACP. Posteriormente, serão cruzadas e relacionadas as informações e seus desdobramentos, de particular importância à apreensão, por serem variáveis que fundamentam a problematização sobre os processos de exclusão e mercantilização territorial dispendidos nos últimos anos sobre o município. Cria-se uma visão panorâmica dos eventos com impacto sobre o caso da Estrada do Engenho.

Parte-se do levantamento feito, entre 2008 e 2009, pelo supervisor de regularização fundiária do município, Jorge Alves, apresentado na Câmara de Vereadores em 2013, que relata que Pelotas apresentava 156 áreas de ocupação irregular e clandestinas (Alves, 2014). Esses espaços são caracterizados como "áreas em que, embora aprovadas pela Prefeitura e demais órgãos [...] quando necessário, fisicamente não são executadas, ou são executadas em descompasso com a legislação ou com atos de aprovação"; conceituadas como áreas que "não obtiveram a aprovação ou autorização administrativa dos órgãos competentes, incluídos aí não só a Prefeitura, como entes Estaduais e Federais" (Alves, 2014, p. 3).

O estudo aponta que, nessas 156 áreas, havia em média 72 lotes em cada uma, assim, seriam aproximadamente 11 mil lotes. Em cada um destes, residindo cerca de três pessoas por família, e números próximos de 390 pessoas por área. Dessa forma, havia mais de 60 mil pessoas habitando em áreas irregulares e 
clandestinas. Complementarmente, os dados do censo do Instituto Brasileiro de Geografia e Estatística (IBGE) para Pelotas em 2010, que coincidem temporalmente com o levantamento, mostram que a cidade possuía cerca de 130 mil unidades habitacionais e 328.275 habitantes. Cruzados os números, observa-se que mais de $8 \%$ das habitações do município eram irregulares e, nessas áreas, encontravam-se mais de $18 \%$ da população (IBGE, 2017).

Já, no ano de 2013, foi lançado o Plano Local de Habitação de Interesse Social (PLHIS) do município. Esse estudo destacou um déficit de 13.598 moradias na cidade, cálculo este que incluía domicílios improvisados, precários, coabitação e famílias com situação de aluguel com valor excessivo (Plhis, 2013a e 2013b), ficando visível qual era o problema habitacional, uma vez que o déficit era de mais de $10 \%$ das moradias. Deste percentual, mais de $80 \%$ era de déficit qualitativo, ou seja, de moradias existentes, mas em situação irregular ou clandestina - habitações que necessitavam de regulamentação documental, infraestrutura urbana, equipamentos e serviços.

Quatro anos depois, em 2017, um novo relatório apontava que, entre 2013 e 2016, foi realizada a regularização fundiária de 10 loteamentos, e que outros 10 estariam em processo; números que equivalem a pouco mais de 6\% dos 156 loteamentos irregulares de 2013 (Alves, 2017). Essa regularização foi feita somente no que diz respeito à questão documental, de modo que foram entregues apenas títulos de propriedade, sem a instalação, em nenhuma das localidades, de equipamentos e serviços. Situação que expressa a compreensão de regularização fundiária e perspectiva de garantia do direito à moradia da PM.
Prosseguindo a análise dos levantamentos feitos no ano de 2013, aponta-se um déficit de mais de 13 mil unidades (Plhis, 2013a), cerca de 11 mil eram domicílios improvisados, precários, etc., habitações que necessitavam de regularização, melhorias e investimento nos territórios em equipamentos e serviços (Alves, 2014). Segundo Pinto (2016), autor que apresenta dados da Representação de Habitação da Caixa Econômica Federal, essas ações não foram feitas (Rehabpel, 2018), permanecendo um premente questionamento: por que a PM adotou como política a construção de novas unidades habitacionais, em detrimento da regularização?

Em continuidade a análise, entre 2013 e 2016, foram entregues 41 empreendimentos do PMCMV, através do qual foram produzidas 7.665 unidades habitacionais, correspondentes a $56 \%$ do déficit habitacional do município (segundo déficit apontado em 2013), construídas com recursos públicos. Complementarmente, é importante destacar que as alterações promovidas pelo Ministério das Cidades, a partir do ano de 2003 no setor habitacional, sobretudo através do PMCMV, "tiveram como objetivo o combate ao problema habitacional para a população de baixa renda" (Pinto, 2016, p. 55). Contudo, segundo os números analisados, essa população representava mais de $80 \%$ do déficit municipal em 2013.

Adicionalmente, se, ao invés de trabaIhar os dados a partir de 2013, analisar-se a partir de 2009 (2009-2016), ano de início da produção através do PMCMV no município, e período de levantamento de dados de Alves (2014), o número de construções passaria de 41 para 60, e as habitações construídas iriam para 11.919 (Pinto, 2016). Tendo em vista isso, 
verifica-se que a produção habitacional por meio do PMCMV deveria ter acabado com o déficit da população de baixa renda - população para a qual o programa foi desenvolvido, de acordo com suas diretrizes. Nessa problemática, insere-se a população residente à margem do canal São Gonçalo, na Estrada do Engenho.

Nota-se que, dessas análises, surgem as respostas para as acusações feitas pelo MP que pesam sobre a comunidade da Estrada do Engenho. Para melhor evidenciá-las, as acusações do MP são apresentadas como indagações abaixo:

- Por que houve aumento no número de famílias que passaram a ocupar o território? (questão que ainda remonta à discussão estabelecida sobre a promulgação do III PDM).

- Se a expulsão dos moradores através de mecanismos jurídicos deveria ser evitada, como se chegou a essa situação?

- Por que a ACP exige a remoção?

- Por que a PM, que construiu a lei do III PDM, não se opôs ao MP? Ou por que o MP não exigiu a planificação do III PDM ao invés de exigir a remoção?

- Como em um cenário de elevada produção habitacional, "voltada para as populações de baixa renda", há um aumento significativo das ocupações na Estrada do Engenho? (Rio Grande do Sul, 2016).

- Diante do elevado número da produção habitacional e dos processos de regularização fundiária que foram desenvolvidos, houve diminuição do número das áreas de ocupação irregular na cidade?

Contrariamente, não diminuiu o número de ocupações, ao invés disso, as ocupações irregulares passaram de 156 (entre 2008-2009), para 162 (em 2014), chegando a 205 ocupações (em 2017 - último ano de atualização dos dados); "mais de 90 mil pessoas" residem em áreas irregulares, o que representa "quase $1 / 3$ da população" do município (Alves, 2017, p. 26).

Percebe-se, assim, que em Pelotas a produção de habitações através do PMCMV poderia ter acabado com o déficit habitacional para a população de baixa renda. No entanto, o que ocorreu foi uma inversão de valores no ato da materialização do programa, que se voltou para as faixas de maior lucratividade e para o mercado, incorrendo no aumento das ocupações irregulares. Fato verificado não somente no município em questão, mas em todo o País (Boulos, 2015).

\section{Por que resistir?}

O aumento da ocupação na Estrada do Engenho seguiu o crescimento das ocupações no município como um todo. Situação que se explica ao se observar os beneficiados pela política de habitação planificada em Pelotas, aos quais as áreas tidas como irregulares são o negativo do qual se alimenta o processo de urbanização e de onde se extrai a mais-valia urbana relativa. Essa questão é uma parte das bem-orquestradas farsas que legitimam os projetos de grupos dominantes para as cidades, criando falsos consensos, cedendo espaços aos interesses empresariais e não atendendo às reivindicações populares (Vainer, 2013).

O PMCMV foi a principal política habitacional planificada no município nas últimas décadas, e por meio dele foram produzidas mais de 11 mil novas moradias (Pinto, 2016). Do mesmo modo como a ACP, o PMCMV carrega o discurso de solução de problemas estruturais, 
com ações pontuais, não passando de estratégias para manutenção dos interesses das elites, favorecidas pelos entes públicos (Nabuco; Primi e Nabuco, 2014).

Influenciados por agentes promotores privados, produzidos com baixa qualidade e alta lucratividade, os impactos dos empreendimentos do PMCMV na cidade são notáveis. Mesmo diante dos estudos que apontaram para o problema habitacional (mais de $80 \%$ qualitativo), a produção foi de $76,49 \%$ para os grupos com renda acima de 3 salários mínimos. Porém, quando dividida por faixa de renda, $23,96 \%$ da produção foi para a faixa 3; $52,45 \%$ para a faixa 2 ; e $23,59 \%$ para faixa 1 . Esses dados representam que, para além de uma inversão de prioridade no ato de planificação da política pública, ocorreu a priorização das faixas de maior lucratividade para o mercado; também apontando o porquê do não avanço em direção à solução dos problemas habitacionais locais. Pois, ao invés de investir em regularização fundiária e urbanismo, optou-se pela produção de novas moradias, através de um processo voltado ao atendimento dos grupos de maior renda.

Além disso, leis municipais foram criadas e alteradas no decorrer da planificação do PMCMV em Pelotas, na intenção de favorecer construtoras e incorporadoras privadas (Pinto, 2016); entre elas, a lei n. 5.603/2009, que instituiu o programa habitacional de interesse social "Pelotas Habitação Digna”. Esse programa viabilizou a construção do maior número de habitações dentro do PMCMV, sem apresentar adendos quanto à sua qualidade para os usuários e trazendo isenções de impostos sobre as construções para seus executores (Pelotas, 2009).
Outra lei sancionada foi a 5.963/2012, especificamente no dia 28 de dezembro, três dias antes do final do mandato do prefeito no período (Pelotas, 2012). Essa lei alterou o perímetro urbano do município e permitiu que se produzissem habitações totalmente desprovidas de infraestrutura, assim como também favoreceu a diminuição e até mesmo a dispensa de áreas verdes e áreas de uso público no interior dos empreendimentos, como anteriormente era previsto em lei, possibilitando construções prejudiciais ao tecido urbano (Kruger, 2018).

Verifica-se, ainda, que tal alargamento do perímetro urbano não ocorreu de forma fortuita, pois "possibilitou o projeto e construção de dois dos empreendimentos pertencentes ao PMCMV" (Pinto, 2016, p. 225) em áreas que extrapolam os limites urbanos - demonstrando as influências de agentes promotores privados sobre as legislações evidentes. Essas intervenções visaram especificamente à facilitação da lucratividade, pois repercutiram em mais de 11 mil unidades habitacionais produzidas com financiamento público. Contudo, o PMCMV sequer diminuiu o número de áreas de ocupação irregular, tornando ainda mais complexos os processos.

$\mathrm{Na}$ cidade transformada em sujeito econômico, de natureza mercantilizada, empresariada, instaurou-se "o poder de uma nova lógica, com a qual se pretende legitimar a apropriação direta dos instrumentos de poder público por grupos empresariais privados" (Vainer, 2013, p. 89). Por meio da disponibilização de recursos, da administração das leis de zoneamento e parcelamento do solo, bem como do desenvolvimento dos planos urbanísticos, foi relegado, ao poder privado, 
o domínio da decisão quanto à produção da cidade. Problemas que, uma vez visualizados, estruturaram o questionamento das afirmações feitas pela ACP, apontando que a falta de fiscalização da PM sobre determinados processos foi estratégica. Do mesmo modo que a negligência quanto à não planificação das instruções previstas no III PDM, ao não se voltar para o suprimento das necessidades da população em situação de vulnerabilidade, estabeleceu um lastro para a efetivação e desenvolvimento da ACP.

Consequentemente, ao exigir a remoção da comunidade residente à margem do canal São Gonçalo, sem considerar a complexa trama que se desenvolvia na cidade, sobretudo no território, o processo jurídico ocultava a desumanização e a objetificação de grupos vitimados historicamente pelo silenciamento e descaso do Estado. Uma ação que refletia a materialização de processos de subalternização, criminalização e perseguição da comunidade, tornando possível, aos herdeiros de uma herança racista e elitista, desfrutarem de seu bônus de exploração - os privilégios sociais.

Tal racionalidade, representada pela $A C P$, delimitava a definição de subjetividades e de espaços físicos que determinavam a cidade, reproduzindo o modelo de avanço a partir dos interesses dos agentes de mercado, deixando um rastro de exclusão e segregação que reforça uma supremacia predatória. A respeito disso, a Imagem 6 demonstra como se desenvolve uma modernização conservadora sobre o território. Uma atualização das antigas ações para a perpetuação do modelo desigual e combinado, reflexo das contradições do modo de produção capitalista.

Imagem 6-Empreendimentos da última década e vazios urbanos no território

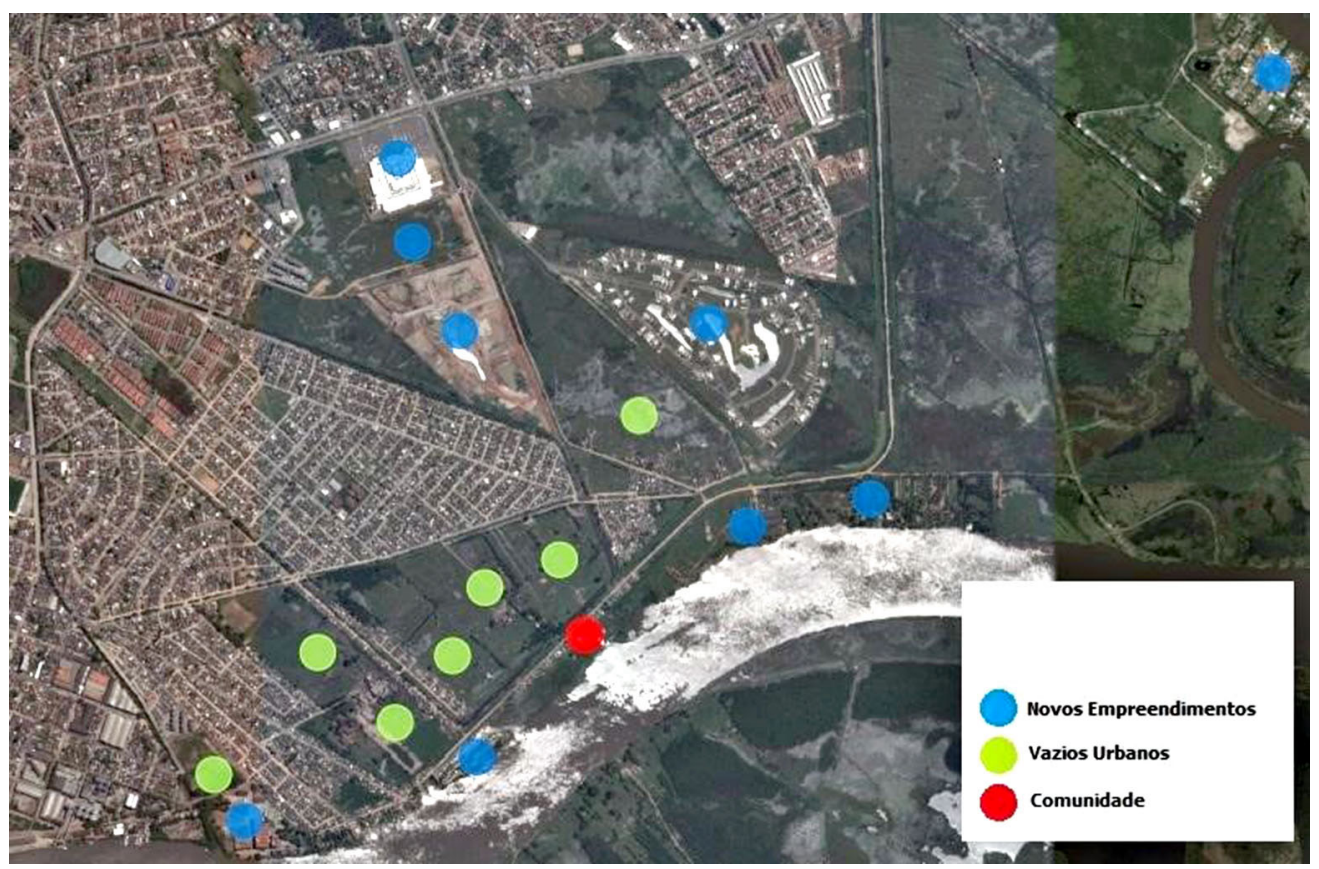

Fonte: Google (2017a; imagem editada). 
Importante esclarecer, que a Imagem 6 foi editada para a visualização de como o território tem sido alterado, a partir da apropriação dos vazios urbanos nele encontrados pelo mercado construtor e do número de lotes que ainda se encontram sem construção - áreas que possibilitam, ainda, o desenvolvimento de novos projetos. Também por meio da Imagem 6 , percebe-se que a comunidade-alvo do processo de remoção ocupa uma área que delimita uma fronteira entre os novos empreendimentos e o acesso aos recursos naturais encontrados. Essa apropriação estabelece novos marcos para o conflito e o desenvolvimento de outras problematizações:

- Sendo a área às margens do canal São Gonçalo considerada de risco - como define a ACP -, por que tal observância se faz somente para população vulnerabilizada?

- Havendo a execução das políticas públicas programadas pelo III PDM - específicas para o local, que tratam do desenvolvimento de infraestrutura urbana, saneamento, etc. e apontam para a construção de projetos específicos de acordo com as legislações ambientais -, continuariam as famílias ameaçadas de remoção por causar danos ambientais?

- Retornando à rememoração histórica feita no princípio desta escrita, não é o canal alvo da descarga de dejetos no transcorrer da história - primeiramente do charque, posteriormente do engenho - e, hoje, de todos os grupos que sem o serviço de coleta de esgoto residem no território? E quem são os maiores afetados por tal contaminação?

- Não são os pescadores artesanais que necessitam de um meio ambiente equilibrado para o desenvolvimento de suas atividades laborais? E não podem ou devem ser estes os maiores guardiões da biodiversidade local?
- Sendo as políticas habitacionais (PMCMV) trabalhadas de forma a contemplar as populações prioritárias e seu desenvolvimento e sendo os direitos constitucionais, como moradia e trabalho, garantidos a esses grupos, por que eles não são contemplados e necessitam procurar essas áreas para fixar residência e desenvolver atividades laborais desreguladas e carentes de proteção?

- Sendo o PMCMV trabalhado em sua amplitude, não somente como possibilidade para a construção de novas moradias, mas como potente instrumento para a regularização fundiária de assentamentos precários, tal realidade não poderia ter sido transformada?

- E, por último, mas não menos importante, qual deveria ser o papel do MP diante dessa situação?

A respeito de cada um desses complexos questionamentos podem vir a ser desenvolvidas novas análises e escritas. Porém, o que se buscou, desde a primeira aproximação a tal realidade, e que acabou se tornando objetivo deste projeto, foi a salvaguarda dos direitos da comunidade. Esse intento se tornou em tensionamento pela não remoção das comunidades originárias e tradicionais, na busca pela proteção social e pela garantia de direitos das famílias residentes no local (Pereira, 2013).

Compreende-se, ainda, que a execução da ACP nos marcos previamente estabelecidos acarretaria irreparáveis danos a esses grupos e poderia vir a deixar o caminho livre para o desenvolvimento de novos processos e projetos de exploração financeira no local. Projetos estes sem benefícios aos guardiões do território, que arcariam com o ônus de sua exploração para que agentes produtores privados lograssem com o bônus, retroalimentando a 
racionalidade de desenvolvimento urbano que tem sido a tônica no País e que se materializa nas cidades (Boulos, 2015).

No caso em tela, a remoção dos moradores da Estrada do Engenho foi impedida após um longo percurso de mobilização da comunidade, de estudos, pesquisas, alianças e denúncias. Processo com envolvimento de inúmeros agentes, técnicos, pesquisadores, extensionistas que transformaram a defesa dos direitos da comunidade em seus objetos de trabalho. Esse esforço conjunto e articulado possibilitou a criação de estudos diversos no bojo dos quais se encontra essa escrita. Projetos desenvolvidos com a comunidade e apresentados às autoridades responsáveis após os moradores e seu grupo de apoio passarem a incidir sobre o processo. Alternativas foram produzidas para a resolução do conflito, sem que os direitos da comunidade fossem negligenciados. Entre as ações previstas estão: a requalificação do território; a reparação das moradias; e o desenvolvimento de atividades para a melhoria das condições de trabalho e renda, para pescadores e catadores.

Ainda no ano de 2017, as problematizações e os tensionamentos tornaram a comunidade e seu grupo de apoio parte do processo jurídico. De modo que as reflexões produzidas foram ouvidas e acatadas, resultando em um novo TAC pactuado. Desse modo, acolhendo as alternativas apresentadas, estabeleceu-se

Imagem 7 - Celebração da assinatura do convênio entre o Ministério Público Estadual e a Prefeitura Municipal de Pelotas ${ }^{4}$

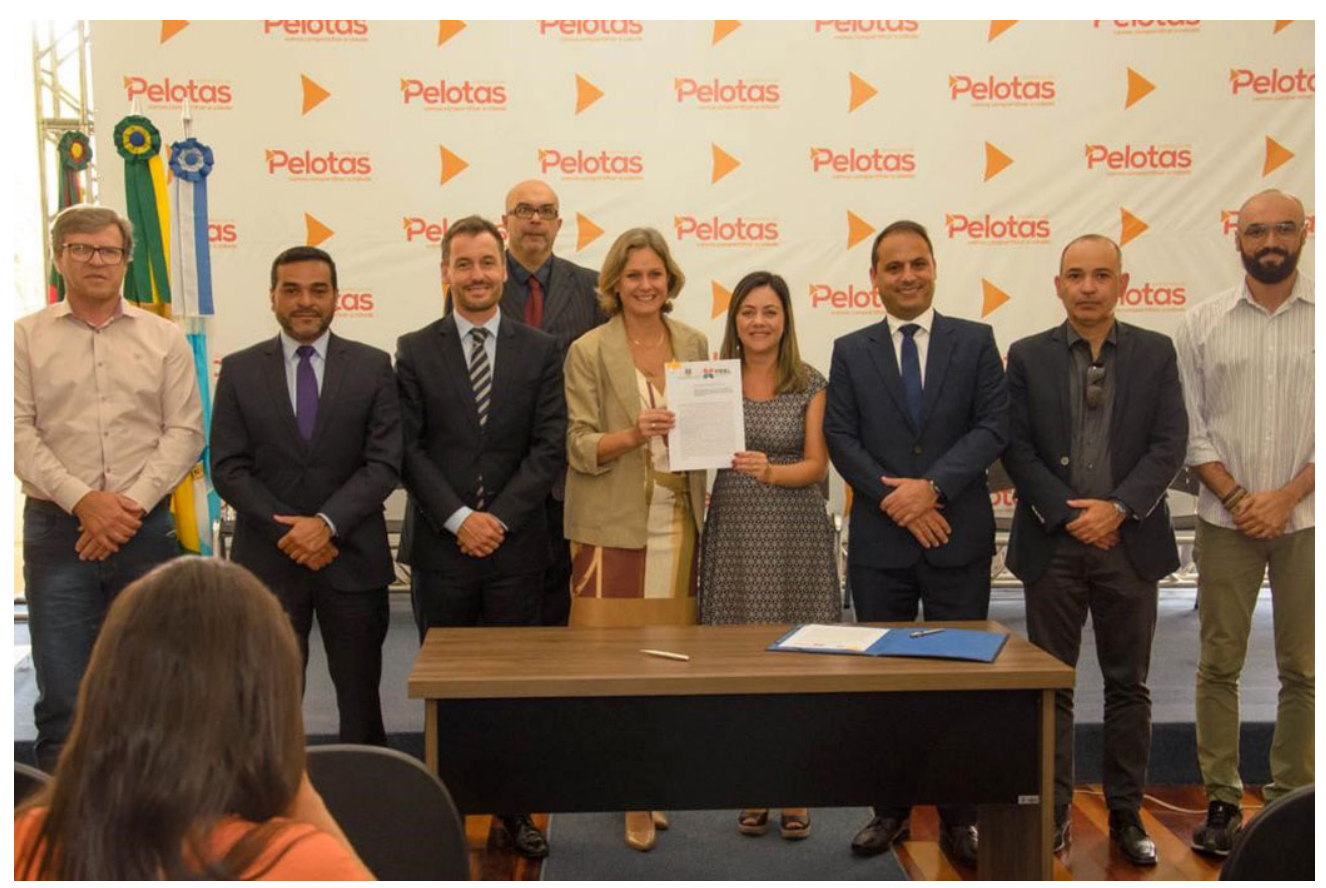

Fonte: Rio Grande do Sul (2020). 
um novo acordo entre os entes envolvidos. Com esse acordo, a PM comprometeu-se com o fornecimento de material e o desenvolvimento de obras de qualificação da infraestrutura, e o MP com a disponibilização de recursos financeiros para a construção de novas moradias para a comunidade - um acordo oficializado no dia 5 de março de 2020 (Rio Grande do Sul, 2020).

\section{Considerações finais}

A investigação relatada neste artigo levou à compreensão de que na ACP não eram considerados os processos históricos que levaram os grupos residentes a ocupar o espaço, e, assim, a relação que eles mantinham com o meio. Tampouco, era considerado que as legislações que se encarregam de proteger os direitos de tal comunidade não vinham sendo respeitadas, o que tornava o processo jurídico um instrumento de criminalização da pobreza e permitia a prosperidade de um projeto de sociabilidade fundamentado na expropriação daqueles que já eram pobres.

Desse modo, a reflexão sobre os interesses especulares do qual o território é alvo - fato justificado pelos vazios urbanos no local (Imagem 6) - e para o qual a PM vinha desenvolvendo projetos sem a participação das comunidades historicamente residentes (Imagem 3) reforçaram as observações e a problematização sobre as ações do Estado no trato das legislações vigentes e dos instrumentos jurídicos referentes a comunidades periféricas e em situação de vulnerabilidade. Isso leva a um questionamento sobre os fatores de influência nos processos e as estratégias de planificação das políticas públicas, pois estas materializam-se em modelos de exclusão potencializados por processos segregacionais, que agravam as manifestações da questão social.

A investigação das estratégias e ações desenvolvidas por meio da análise da ACP permitiu a compreensão de que programas e ações apresentados enquanto processos necessários para a proteção da vida e do meio ambiente, ao desassociarem-se das relações materiais que os circulam - como as manifestações da questão social -, podem tornar-se instrumentos que aprofundam modelos de desproteção, degradação territorial e socioambiental, que impactam e atentam contra a vida, uma contradição que move o sistema capitalista.

O tensionamento e a problematização das práticas públicas com influência para tal realidade, relacionada às atividades desenvolvidas por agentes construtores no entorno do território, trouxeram à luz a interdependência dos processos. Em outras palavras, ações econômicas e políticas de influência sobre a exclusão e mercantilização do território, que se vinculam a uma perspectiva muito específica de gestão do Estado, na qual se impõe a primazia do mercado, que age enquanto agente regulador.

Esse projeto, ao buscar inicialmente compreender as relações estabelecidas sobre o território, constatou o processo de mistificação provocada na execução de ações coordenadas por agentes públicos em descompasso com a realidade social e com os perigos da utilização ideologizada de estatutos jurídicos. Tratou de se tornar ferramenta de articulação e resistência à violação de direitos, de modo que se desenvolvendo em um processo de construção de conhecimentos emancipatórios, 
fosse capaz de instrumentalizar pesquisadores, coletivos, movimentos sociais e os próprios moradores (da Estrada do Engenho), para a busca de proteção e garantia do direito humano fundamental à moradia.

Dessa forma, apresentam-se possibilidades concretas de alinhar a pesquisa acadêmica, a partir de seus métodos e técnicas, às demandas coletivas, tratando as manifestações da questão social como caminho para o alcance de transformações concretas. Isto quando a universidade, espaço político de conflito entre forças sociais, uma arena de produção de saber, consciente de suas possibilidades e limitações, supera a redução da ciência a meras soluções técnicas e se une às lutas dos movimentos sociais. Torna-se possível, assim, a produção e o reconhecimento de formas de saber que são estratégias para resistência, sobrevivência e enfrentamento da lógica posta; ampliando o debate sobre o direito à cidade e a atuação do Estado nos marcos do capital, traduzindo uma ferramenta para o desenvolvimento de lutas outras, de maneira politicamente posicionada, em favor das populações criminalizadas, dos grupos que resistem na ocupação do solo urbano e que, assim, denunciam o modelo de planejamento voltado para mercado, retroalimentado por políticas públicas que negam o acesso ao direito de existir.
É importante ainda aclarar que o relato ora apresentado poderia retratar situações de outras tantas cidades brasileiras, tendo em vista que externaliza as racionalidades que fundamentam os processos e o modelo de desenvolvimento urbano instaurado sobre a nação, assim como, também, as estratégias de resistência de comunidades e pesquisadores militantes. Ademais, analisa como uma $A C P$, constituída enquanto processo, pode não observar os múltiplos interesses em conflito e as relações históricas anteriores que instituíram o problema e, assim, transformar-se em um documento de criminalização das vítimas. Processos jurídicos não se estabelecem de maneira isolada de seus contextos sociais, econômicos e políticos, e tampouco as ações desenvolvidas por pesquisadores.

Por fim, ressalta-se que foi a opção de trabalhar em aliança com a comunidade e de construir de maneira solidária as estratégias, técnicas e táticas para abordagem da situação, que permitiu que os resultados fossem alcançados. 0 trabalho coletivo foi o responsável pelo reconhecimento da necessidade de tensionamento sobre a ACP, possibilitando desestabilizar o processo e alcançar êxito na transformação da realidade posta, protegendo e preservando modos de habitar, a vida, a cultura, a história e as tradições locais. A Estrada do Engenho resiste. 


\section{[I] https://orcid.org/0000-0002-6181-4652}

Universidade Católica de Pelotas, Centro de Ciências Jurídicas, Econômicas e Sociais, Programa de Pós-Graduação em Políticas Sociais e Direitos Humanos. Pelotas, RS/Brasil.

contatorafaelkruger@gmail.com

\section{[II] http://orcid.org/0000-0002-6368-9138}

Universidade de São Paulo, Faculdade de Economia, Administração e Contabilidade, Pós-Graduação em Administração de Organizações. Ribeirão Preto, SP/Brasil.

carolgkruger@gmail.com

\section{[III] https://orcid.org/0000-0002-1660-8200}

Universidade Católica de Pelotas, Curso de Graduação em Serviço Social, Programa de Pós-Graduação em Política Social e Direitos Humanos. Pelotas, RS/Brasil.

cristinejrib@gmail.com

\section{Notas}

(1) Por questões conjunturais desencadeadas, o trabalho de acompanhamento e assessoria tornou-se um projeto de pesquisa de mestrado apresentado ao Programa de Pós-Graduação em Política Social e Direitos Humanos da Universidade Católica de Pelotas. Este foi produzido em parceria com os habitantes do território, resultando em uma dissertação escrita e apresentada nos moldes metodológicos da pesquisa militante.

(2) Forma de vida e relação com o ambiente e no ambiente (Lefebvre, 2001).

(3) Expressão que manifesta o conflito entre capital e trabalho.

(4) Na foto, estão a refeita de Pelotas, Secretários Municipais, Promotores do Ministério Público Estadual, representantes das universidades e do grupo de apoio dos moradores. Para mais informações sobre o processo de autorização/aprovação para a construção do novo loteamento, acesse: https://www.mprs.mp.br/noticias/50756/ e http://www.pelotas.rs.gov.br/noticia/ convenio-traz-solucao-para-o-loteamento-da-estrada-do-engenho. 


\section{Referências}

ACSELRAD, H. (2010). Ambientalização das lutas sociais - o caso do movimento por justiça ambiental. Disponível em: <https://www.scielo.br/pdf/ea/v24n68/10.pdf>. Acesso em: 16 ago 2020.

ACSELRAD, H.; MELLO. C. C. A.; BezerRA, G. N. (2009). O que é justiça ambiental. Rio de Janeiro, Garamond.

AL-ALAM, C. C. (2017). "Passo dos Negros". In: LONER, B. A.; GILL, L. A.; MAGALHÃES, M. O. (orgs.). Dicionário de História de Pelotas. Pelotas, Editora da UFPel.

ALVES, J. (2014). Regularização fundiária. Pelotas, 16 de outubro. 320 slides. Apresentação em Power Point.

(2017). Regularização fundiária: a cidade que temos e queremos. Pelotas, 7 de julho de. 337 slides. Apresentação em Power Point.

BAUER, M. W.; GASKELL, G. (orgs.) (2012). Pesquisa qualitativa com texto, imagem e som: um manual prático. Petrópolis/RJ, Vozes.

BOULOS, G. (2015). Por que ocupamos? São Paulo, Autonomia Literária.

BRASIL (2001). Lei n. 10.257/2001. Regulamenta os Artigos. 182 e 183 da Constituição Federal. Disponível em: http://www.planalto.gov.br/ccivil_03/leis/LEIS_2001/L10257.htm. Acesso em: 9 out 2017.

BRINGEL, B.; VARELLA, R. V. S. (2016). A pesquisa militante na América Latina hoje: reflexões sobre as desigualdades e as possibilidades de produção de conhecimentos. Revista digital de direito administrativo. Faculdade de Direito de Ribeirão Preto. Universidade de São Paulo, v. 3, n. 3, pp. 474-489.

COGOY, C. (2017). Famílias lutam contra a remoção. Diário da Manhã, ano 39, n. 62, p. 6, 4 set.

COLL, L. (2017). Estamos sob pressão daqueles que podem: em Pelotas, comunidade sofre ameaça de remoção. Disponível em: https://www.sul21.com.br/jornal/estamos-sob-pressao-daqueles-quepodem-em-pelotas-comunidade-sofre-ameaca-de-remocao/. Acesso em: 20 set 2017.

CUNHA, G. C.; SANTOS, A. M. dos (2010). "Economia Solidária e Pesquisa em Ciências Sociais: desafios Epistemológicos e Metodológicos”. In: HESPANHA, P.; SANTOS, A. M. (orgs.). Economia solidária: questões teóricas e epistemológicas. Coimbra, Almedina.

DEFENDER (2010). Engenho será restaurado. Disponível em: http://defender.org.br/noticias/riogrande-do-sul/pelotasrs-antigo-engenho-sera-restaurado/. Acesso em: 9 set 2017.

ESTRADA DO ENGENHO (2017). Álbuns. Disponível em: https://www.facebook.com/pg/ EstradaDoEngenhoResiste/photos/?ref=page_internal. Acesso em: 8 jun 2020.

FILHO, A. E. (2017). Retirando os pobres para redistribuir os ricos - Sai já daí. Disponível em: http:// www.observatoriopelotas.com.br/2017/05/14/retirando-os-pobres-para-redistribuir-os-ricossai-ja-dai/. Acesso em: 24 nov 2017.

GALHARDO, R. (2008). Lula: crise é tsunami nos EUA e, se chegar ao Brasil, será 'marolinha'. Disponível em: https://oglobo.globo.com/economia/lula-crise-tsunami-nos-eua-se-chegar-ao-brasil-seramarolinha-3827410\#ixzz5HrkHrttU. Acesso em: 8 jun 2018. 
GOOGLE Earth. (2017a). Vista aérea da Estrada do Engenho, Pelotas, de 2010. Disponível em: < https:// www.google.com/maps/@-31.77304,-52.31291,15z/data=!3m1!1e3>. Acesso em: 17 nov 2017.

(2017b). Vista aérea da Estrada do Engenho, Pelotas, de 2016. Disponível em: <https://www. google.com/maps/@-31.77304,-52.31291,15z/data=!3m1!1e3>. Acesso em: 17 nov 2017.

GUTIERREZ. E. J. B. (2001). Negros, charqueadas e olarias: um estudo sobre o espaço pelotense. Pelotas, Ed. UFPEL.

HARVEY, D. (2005). O novo imperialismo. São Paulo, Loyola.

IBGE (2017). Pelotas. Disponível em: http://cidades.ibge.gov.br/xtras/perfil.php?codmun=431440. Acesso em: 2 jul 2017.

IDEALIZA (2014). Parque UNA Pelotas. Disponível em: http://www.parqueunapelotas.com.br/site/. Acesso em: 25 nov 2017.

KOWARICK, L. (1993). A espoliação urbana. São Paulo, Paz e Terra.

KRUGER, N. R. M. (2018). O plano perfeito: da retórica sobre o direito à moradia ao Programa Minha casa Minha Vida a negação do habitar. Dissertação de mestrado. Pelotas, Universidade Católica de Pelotas.

LEFEBVRE, H. (2001). O direito à cidade. São Paulo, Centauro.

MARICATO, E. (2015). Para entender a crise urbana. São Paulo, Expressão Popular.

MARTINS, J. S. (1997). Exclusão social e a nova desigualdade. São Paulo, Paulus.

MORGAN, D. (1997). Focus group as qualitative research. Qualitative Research Methods Series 16. Londres, Sage Publications.

MOURA. R. M. G. R de (2006). Habitação popular em Pelotas (1880-1950): entre políticas públicas e investimentos privados. Tese de doutorado. Porto Alegre, Pontifícia Universidade Católica do Rio Grande do Sul.

MUNARETTO, S. (2017). Estrada do Engenho resiste: a luta de uma comunidade pelo direito à moradia. Disponível em: http://reporterpopular.com.br/estrada-do-engenho-resiste-luta-de-umacomunidade-pelo-direito-moradia/. Acesso em: 9 set 2017.

NABUCO, A.; PRIMI, L.; NABUCO, W. (2014). Luta por um Teto. Revista Caros Amigos, jul. Entrevista Guilherme Boulos.

NETTO, J. P. (2011). Introdução ao estudo do método de Marx. São Paulo, Expressão Popular.

NIGRO, C. D. (2007). (In)sustentabilidade urbana. Curitiba, Ibpex.

OLIVEIRA, F. de (2013). Crítica a razão dualista o ornitorrinco. São Paulo, Boitempo.

PAPALÉO, M. T. (1991). “O pensamento político de Norberto Bobbio - Algumas considerações". In: RECH, H.; FREITAS, J. (orgs.). Teoria da organização nos clássicos e uma incursão na filosofia política contemporânea. Rio Grande, Editora da FURG.

PELOTAS (1968). Lei n. 1672/1968. Disponível em: http://intranet.pelotas.com.br/politica_urbana_ ambiental/planejamento_urbano/I_plano_diretor/I_plano_diretor.pdf. Acesso em: 19 maio 2018.

(1980). Lei n. 2565/80. Institui o II Plano Diretor de Pelotas. Disponível em: http://www2. camarapel.rs.gov.br/camarapel.rs.gov.br/legislacao/codigodeedificacoesplanodiretor/ Codigodeedificacoes/Planodiretor\%20revisado.pdf. Acesso em: 19 maio 2018. 
PELOTAS (2008). Lei municipal n. 5.502/2008. Disponível em: http://www.pelotas.com.br/politica_ urbana_ambiental/planejamento_urbano/III_plano_diretor/lei_iii_plano_diretor/arquivos/ lei_5502.pdf. Acesso em: 5 dez 2015.

(2009). Lei municipal n. 5.603/2009. Disponível em: https://www.leismunicipais.com.br/.../ pelotas/lei.../5603/lei-ordinaria-n-5603.pdf. Acesso em: 25 jan 2015.

(2012). Lei municipal n. 5.963/2012. Disponível em: http://www.pelotas.rs.gov.br/interesse_ legislacao/leis/2012/LEl5963.pdf. Acesso em: 26 jun 2016.

PEREIRA, C. P. (2013). Proteção social no capitalismo: contribuição à crítica de matrizes teóricas e ideológicas conflitantes. Tese de doutorado. Brasília, Universidade de Brasília.

PINTO, J. V. (2016). Contribuições para estudo do "Programa Minha Casa Minha Vida" para uma cidade de porte médio, Pelotas-RS: caracterização das empresas construtoras e incorporadoras privadas $e$ inserção urbana. Dissertação de mestrado. Pelotas, Universidade Federal de Pelotas.

PLHIS (2013a). Plano local de habitação de interesse social de Pelotas - Etapa 3: estratégias de ação. Pelotas, 3C Arquitetura e Urbanismo.

(2013b). Plano local de habitação de interesse social de Pelotas. Disponível em: <plhispelotas. blogspot.com>. Acesso em: 22 maio 2014.

REHABPEL (2018). Empreendimentos PMCMV em Pelotas [mensagem pessoal]. Mensagem recebida por<contatorafaelkruger@gmail.com>em 10 ago.

RHEINGANTZ, C. G. (2004). O charqueador. Diário Popular. Pelotas, ano 114, n. 274, p. 3, 9 jun.

RIBEIRO, R. B. (2017). Dique [mensagem pessoal]. Mensagem recebida por <contatorafaelkruger@ hotmail.com> em 24 nov.

RIO GRANDE DO SUL (2012). Código estadual de meio ambiente. Porto Alegre, Assembleia Legislativa.

(2016). Acordo judicial firmado sobre a Ação Civil Pública n. 022/1.14.0007280-6. Disponível em: http://www1.tjrs.jus.br/busca/?tb=proc. Acesso em: 9 set 2017.

(2020). Pelotas: MP e Município assinam convênio para reassentamento de famílias e recuperação de área de preservação permanente. Disponível em: https://www.mprs.mp.br/ noticias/50756/. Acesso em: 8 jun 2020.

ROSENTHAL, M. D.; GONÇALVES, E. A. (2014). Marambaia: história, memória e poética. Disponível em: https://periodicos.ufpel.edu.br/ojs2/index.php/Arte/article/view/4810/3592. Acesso em: 9 set 2017.

SAQUET, M. A.; SILVA, S. S. (2008). Milton Santos: concepções de geografia, espaço e território. Ver. Geo UERJ. Rio de Janeiro, v. 2, n. 18, pp. 24-42.

VAINER, C. (2013). A cidade do pensamento único: desmanchando consensos. Petrópolis, Vozes. 